\title{
Tissue Factor Is a Major Stimulus for Vegetation Formation in Enterococcal Endocarditis in Rabbits
}

\author{
Thomas A. Drake, George M. Rodgers, \\ and Merle A. Sande \\ The Medical Service, San Francisco General Hospital, \\ Department of Medicine and Cancer Research Institute, \\ University of California San Francisco, and Gladstone \\ Foundation Laboratory for Cardiovascular Disease, \\ San Francisco, California 94110
}

bstract. We examined the possible mechanisms of local initiation of coagulation in vegetation formation in enterococcal endocarditis by using a rabbit model. Contact activation and tissue factor expression by freshly excised aortic valves were assessed using assays developed for use with cultured cells. Bacteria alone lacked procoagulant activity and contact activation of plasma by excised valves did not occur. 4-d infected but not control valves expressed significant tissue factor activity ( $231 \pm 17 \mathrm{mU}$ vs. $51 \pm 7 \mathrm{SE}$ ), which did not correlate with numbers of bacteria in vegetations. Tissue factor activity was also present in valves from rabbits infected for 1 and $2 \mathrm{~d}$, as well as those from granulocytopenic and monocytopenic animals. Our findings suggest that tissue factor, expressed by host cells in response to infection, is a major stimulus for fibrin deposition in vegetation development.

\section{Introduction}

Recent investigations have led to an understanding of the initiating event in the pathogenesis of infective endocarditis, the adherence of circulating organisms to sterile fibrin-platelet thrombi in the surface of damaged valves (1). However, the factors responsible for subsequent vegetation development have not been elucidated. The coagulation system clearly plays a critical role at this stage, as warfarin anticoagulation prevents vegetation formation (2). This study examines the mechanisms by which cardiac valve infection may initiate local activation

Dr. Rodgers is a recipient of a National Heart, Lung, and Blood Institute Clinical Investigator Award 1K08HL01031-02.

Received for publication 16 December 1983 and in revised form 10 February 1984.

J. Clin. Invest.

(C) The American Society for Clinical Investigation, Inc. 0021-9738/84/06/1750/04 \$1.00

Volume 73, June 1984, 1750-1753 of coagulation. First, the intrinsic coagulation pathway might be activated by exposed connective tissue components of the damaged valve (3) or by bacterial cell wall elements (4). Secondly, tissue factor expression by host cellular elements could initiate the extrinsic pathway (5). Third, it is known that some bacteria can directly activate coagulation proteins (6), although most endocarditis-associated organisms cannot. We determined the relative role played by each of these mechanisms in an experimental model of enterococcal endocarditis.

\section{Methods}

Materials. Streptococcus fecalis strains cor and hol (isolated from patients with endocarditis) were maintained at $-70^{\circ} \mathrm{C}$ before use. Catheters were made from PE 90 polyethylene tubing (Clay Adams, Parsippany, NJ). Mechlorethamine $\mathrm{HCl}$ was from Merck Sharp \& Dohme (West Point, PA). Human Factor VII was provided by Dr. George J. Broze, Jr. (Washington University, St. Louis, MO) and activated as described (7); its specific activity was $53 \mathrm{U} / \mu \mathrm{g}$. Factor $\mathrm{X}$ and prothrombin were purified from human plasma as described (8); Factor X-specific activity was 160 $\mathrm{U} / \mathrm{mg}$. Bovine Factor VII/X-deficient plasma, rabbit brain cephalin, bovine serum albumin (BSA-Fraction V), and rabbit brain thromboplastin were from Sigma Chemical Co. (St. Louis, MO). Polystyrene petri dishes $(35 \times 10 \mathrm{~mm})$ were supplied by Falcon Labware (Oxnard, CA). The radiolabeled protease substrate benzoyl-L-prolyl-L-phenylalanyl$\mathrm{L}$-arginyl- ${ }^{14} \mathrm{C}$-anilide and Omnifluor were products of New England $\mathrm{Nu}-$ clear (Boston, MA). Unlabeled benzoyl-L-prolyl-L-phenylalanyl-L-arginylanilide was from Vega-Fox Biochemical Div., Newbery Energy Corp. (Tucson, AZ).

Establishment of endocarditis. White New Zealand rabbits (male and female, $1.8-2.5 \mathrm{~kg}$ ) were anesthetized and the left heart catheterized as described (9). $1 \mathrm{~d}$ later, $4 \times 10^{7} \log$ phase $S$. fecalis in $1 \mathrm{ml}$ saline (or saline alone for controls) were injected via the catheter, which was then removed. Over $95 \%$ of animals thus infected developed endocarditis, manifested by bacteremia and temperature $>39.6^{\circ} \mathrm{C}$ within $4 \mathrm{~d} .37$ rabbits were infected and 11 were not infected. Four more rabbits thus treated were rendered leukopenic by a single intravenous injection of mechlorethamine $\mathrm{HCl}(2.5 \mathrm{mg} / \mathrm{kg}) 3 \mathrm{~d}$ before infection; two were infected and two controls were not. Leukocyte counts were determined on the day of infection and at the time of death, $24 \mathrm{~h}$ later, being $<600 / \mathrm{mm}^{3}$ on each occasion. 18 additional rabbits were treated in the following manner: 5 were neither catheterized nor infected; 3 were not catheterized but were injected intravenously with the bacterial inoculum (these did 
not develop endocarditis); and 10 uninfected rabbits had the catheter left in place for a total of 3 or $5 \mathrm{~d}$ before death.

Tissue factor assay. Aortic valves were excised from rabbits at 20 min and 1,2, or $4 \mathrm{~d}$ after catheter removal. Animals were killed by rapid intravenous injection of $250 \mathrm{mg}$ pentobarbital several minutes after administration of $800 \mathrm{U}$ i.v. heparin. Hearts were immediately removed, opened, and the aortic valve flushed gently with $20 \mathrm{mM}$ Tris$\mathrm{HCl}, 150 \mathrm{mM} \mathrm{NaCl}, 2 \mathrm{mg} / \mathrm{ml} \mathrm{BSA} \mathrm{pH} 7.4$ (assay buffer). All three cusps with adherent vegetations were excised using fine forceps and iris scissors, avoiding inclusion of valve ring substance and placed in a petri dish containing $1 \mathrm{ml}$ assay buffer. Tissue factor activity was then measured as has been described for cultured cells (10), incubating valves with purified Factors VII $_{a}(20 \mathrm{ng})$ and $X(10 \mu \mathrm{g})$. The Factor $X_{a}$ generated was measured by clotting assay (10). Clotting times were compared with a standard curve generated by using rabbit brain thromboplastin, Factor $\mathrm{VII}_{\mathrm{a}}$, and Factor X. Stock thromboplastin $(0.001 \mathrm{ml}, 7 \mu \mathrm{g}$ protein $)$ was designated as having $1 \mathrm{U}$ of tissue factor activity. Valve tissue factor activities were related to a standard curve constructed with thromboplastin dilutions and expressed in terms of milliunits thromboplastin standard.

Contact activation assay. Intrinsic coagulation pathway activation was assessed by measuring the conversion of prekallikrein to kallikrein, a Factor $\mathrm{XII}_{\mathrm{a}}$-dependent reaction, while plasma was incubated over a glass surface and over an albumin-coated petri dish containing either control or infected aortic valves obtained as described for the tissue factor assay. Details of this assay have been described previously (11).

Determination of bacterial procoagulant activity. The ability of bacteria to activate Factor $\mathrm{X}$ or prothrombin was studied using the Factor $\mathrm{X}_{\mathrm{a}}$ assay (10) or a prothrombinase assay, respectively. $S$. fecalis strain cor was grown overnight in trypticase soy broth, washed twice in saline, and resuspended in assay buffer. The final concentration of bacteria in each incubation was $2 \times 10^{8}$ colony-forming units per milliliter. In the prothrombinase assay, bacteria in $1 \mathrm{ml}$ assay buffer were incubated with $100 \mu \mathrm{g}$ purified prothrombin and $10 \mathrm{mM} \mathrm{CaCl}_{2}$. Thrombin generation was measured by a clotting time (12). The tissue factor expression of bacteria was studied using the assay described above; for this assay, bacteria grown overnight in broth containing $50 \%$ rabbit serum were also examined.

\section{Results}

Tissue factor expression by excised heart valves. Aortic valves of rabbits infected for $4 \mathrm{~d}$ with either strain of $S$. fecalis expressed significantly greater tissue factor activity $(110-600 \mathrm{mU}$, mean $231.1 \pm 17.2 \mathrm{SE})$ than did valves from control rabbits $(\leq 90 \mathrm{mU}$, mean 51.2 \pm 7.1$)$. Valves of five normal rabbits and three rabbits injected intravenously with the bacterial inoculum but not catheterized had levels of tissue factor comparable to those of catheterized controls ( $\leq 30$ to $110 \mathrm{mU}$ ). Deletion of Factor $\mathrm{VII}_{\mathrm{a}}$, Factor X, or both from the incubation medium proved that the majority of activity measured represented tissue factor (Fig. 1). Factors VII $_{\mathrm{a}}$ and $\mathrm{X}$ incubated in buffer without aortic valves generated no activity. The magnitude of activity of $4 \mathrm{~d}$ infected valves did not significantly correlate with the total number of bacteria in vegetations $(r=0.52, P>0.1)$; nor with wet weight $\left(r_{\mathrm{s}}=0.67, P>0.05,<0.1\right)$. Expression of tissue factor by aortic valves at levels greater than in controls occurs within $24 \mathrm{~h}$ of infection in most animals (Fig. 2). Mean activities ( \pm SEM) of valves infected for 1,2 , and $4 \mathrm{~d}$ (strain cor only) were not

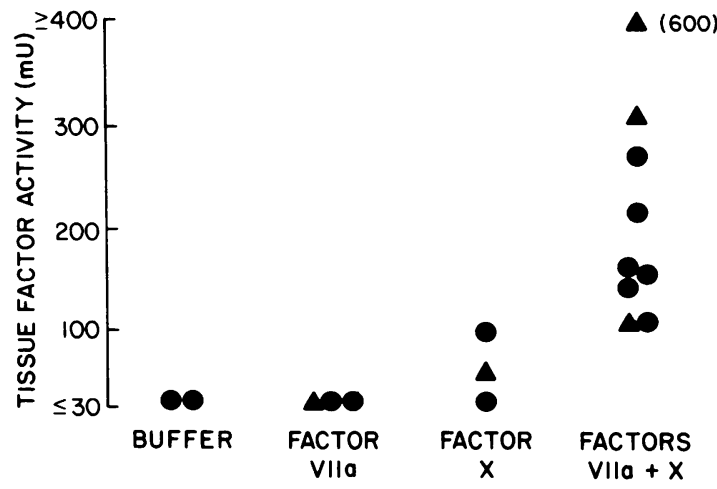

Figure 1. Tissue factor activity of 4-d infected valves. Tissue factor activity was assayed as described in Methods using buffer and Factors $\mathrm{VII}_{\mathrm{a}}$ and $\mathrm{X}$, or each alone. Each point represents one animal infected with strain cor $(\bullet)$ or hol $(\mathbf{\bullet})$.

different $(169.8 \pm 20.6,168.8 \pm 27.0$, and $176.7 \pm 23.2 \mathrm{mU}$, respectively, $P>0.5$ ). Overall, combining data for days 1 to 4 , mean tissue factor expression in infected valves $(169.1 \pm 12.3)$ was significantly greater than controls $(63.6 \pm 12.4, P<0.001)$. Total numbers of bacteria in vegetations (mean $\pm \mathrm{SE}, \log 10$ colony-forming units) increased from $3.7 \pm 0.1$ at $20 \mathrm{~min}$ postinfection to $4.9 \pm 0.1$ at $1 \mathrm{~d}, 6.0 \pm 0.2$ at $2 \mathrm{~d}$, and $6.9 \pm 0.2$ at 4 d. Although mean $( \pm \mathrm{SE})$ vegetation size after $24 \mathrm{~h}$ of catheterization alone was comparable to that after 24 or $48 \mathrm{~h}$ of infection (19.6 \pm 1.7 vs. $17.9 \pm 1.3$ and $17.4 \pm 0.8 \mathrm{mg}$ valve weight, respectively), tissue factor expression of the valves with sterile catheterinduced vegetations was lower in five of six rabbits (Fig. 2, 0 d) being in the same range as normal valves. Similar results were also obtained from valves of uninfected rabbits in which catheters had been left in place for $3(n=6)$ or $5(n=4) \mathrm{d}$ (i.e., for total study durations equal to those of 2- and 4-d infections); valve weights were $15.8 \pm 4.1$ and $26.1 \pm 7.3 \mathrm{mg}$ (mean $\pm \mathrm{SE}$ ), respectively. Tissue factor activity of valves from

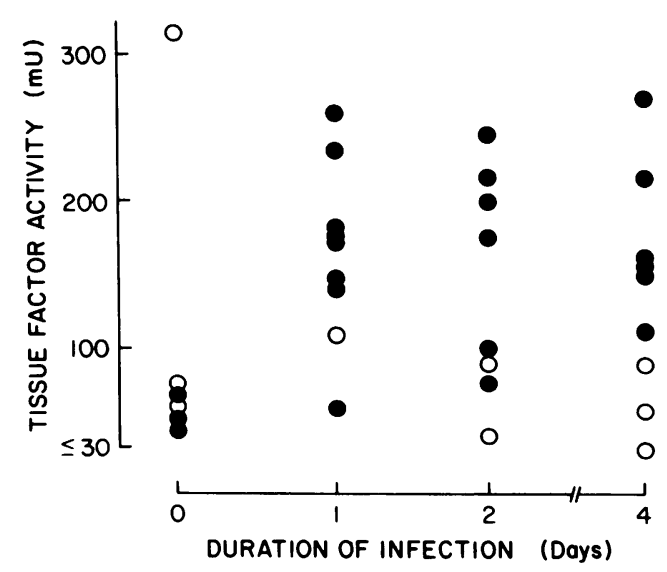

Figure 2. Tissue factor activity of infected $(\bullet)$ and uninfected $(0)$ valves (cor strain only), at $0(20 \mathrm{~min}), 1,2$, and $4 \mathrm{~d}$. 
two leukopenic rabbits (500 and 600 total leukocytes $/ \mathrm{mm}^{3}$ with 0 and 9 total granulocytes, and 12 and 33 total monocytes/ $\mathrm{mm}^{3}$ ) infected for $1 \mathrm{~d}$ were 290 and $600 \mathrm{mU}$ compared with 65 and $110 \mathrm{mU}$ in two leukopenic controls. Neither granulocytes and monocytes were observed histologically in these same valves examined after the tissue factor assay.

Assay for contact activation by excised heart valves. Kallikrein generation during incubation of fresh-frozen plasma is dependent on Factor XII activation. The presence of 4-d infected $(n=3)$ or control $(n=2)$ aortic valves did not increase the amount of kallikrein detected above the low level generated in albumincoated plastic petri dishes alone, while incubation of plasma alone in glass tubes generated significant kallikrein activity (data not shown). Vegetation size and bacterial titer of the valves tested were comparable to those shown to express significant tissue factor activity.

Assays for procoagulant activity of $S$. fecalis in culture. Suspensions of $S$. fecalis in numbers equal to or greater than those found in infected valves had no demonstrable prothrombinase, Factor X-activating, or tissue factor activity.

\section{Discussion}

This study of experimental enterococcal endocarditis demonstrates that activation of coagulation, ultimately leading to vegetation formation, occurs via enhanced expression of tissue factor by infected valves. Tissue factor is a membrane-associated lipoprotein which initiates coagulation by specifically binding Factor $\mathrm{VII}_{\mathbf{a}}$, forming a complex capable of activating Factor $\mathrm{X}$ (5); Factor $X_{a}$ in turn activates prothrombin to thrombin, resulting in deposition of fibrin, an essential structural component of the vegetation. Alternate mechanisms of coagulation activation (Factor XII activation as measured by the kallikrein assay and direct bacterial activation of Factor $\mathrm{X}$ or prothrombin) were not detected in this model. Under the experimental conditions used, bacterial infection of susceptible cardiac valves was by itself sufficient to significantly increase tissue factor expression, while catheter trauma in the absence of infection was not. The levels obtained for infected valves were comparable to those expressed by $6 \times 10^{5}$ nonvascular cells (human fibroblast or bovine corneal endothelial cells) described in previous studies (10). Cultured bovine aortic endothelial cells (unstimulated) express negligible activity by comparison.

The use of purified Factors VII $_{\mathrm{a}}$ and $\mathrm{X}$ in the first stage of the tissue factor assay make this assay specific for tissue factor, since Factor $\mathrm{X}$ activation is directly related to the quantity of tissue factor expressed (13). Platelets, monocytes, and endothelial cells undoubtedly contribute to the local coagulation process by amplifying tissue factor-generated Factor $\mathrm{X}_{\mathrm{a}}$ activity via enhanced prothrombinase complex assembly on their surfaces (14, 15). However, this activity would not be recognized by the tissue factor assay used here, and by itself could not initiate coagulation.

Several specific components of the infected valve may be responsible for tissue factor expression. Cellular elements of the lesion are bacteria, platelets, and occasional leukocytes intermixed with fibrin in the substance of the vegetation, stromal cells in the valve connective tissue core, and endothelial cells lining the valve surfaces. Neither platelets nor bacteria express tissue factor, but each has been shown to stimulate its activity in other cells (16-18). Vascular endothelial cells, although normally lacking tissue factor activity, will express significant activity in response to a variety of stimuli $(5,16,17)$. Fibroblasts inherently express tissue factor (10), and those in the valve core may be exposed as valve destruction occurs. Monocytes have been proposed as the source of procoagulant activity in vegetations (19). They have also been shown in vitro to express tissue factor in response to platelets, endotoxin, and in collaborative function with lymphocytes that have been exposed to bacterial products (5). Granulocytes and lymphocytes, in contrast, do not express tissue factor in vitro $(5,13)$. Monocytes are usually not major constituents of the vegetation and in our study, infected valves of leukopenic (monocytopenic and granulocytopenic) rabbits expressed amounts of tissue factor equivalent to those of nonleukopenic animals. It is thus likely that the local host cells (stimulated or damaged endothelial cells, fibroblasts, and, when present, monocytes) all express tissue factor in response to the continued presence of bacteria, thereby causing progressive fibrin deposition and vegetation enlargement.

\section{Acknowledgments}

We thank Michael G. Rusnak for technical assistance, and Dr. Marc A. Shuman for his advice and review of the manuscript.

This study was supported by grants from the American Heart Association, Northern California Chapter; Academic Senate, University of California, San Francisco; and by Ciba-Geigy Limited, Basle, Switzerland.

\section{References}

1. Freedman, L. R. 1982. Infective endocarditis and other intravascular infections. Plenum Medical Book Co., New York. 27-61.

2. Hook, E. W., III, and M. A. Sande. 1974. Role of the vegetation in experimental Streptococcus viridans endocarditis. Infect. Immun. 10:1433-1438.

3. Cochrane, C. G., and J. H. Griffin. 1982. The biochemistry and pathophysiology of the contact system of plasma. Adv. Immunol. 33:241306.

4. Kalter, E. S., W. C. van Dijk, A. Timmerman, J. Verhoef, and B. N. Bouma. 1983. Activation of purified human plasma prekallikrein triggered by cell wall fractions of Escherichia coli and staphylococcus aureus. J. Infect. Dis. 148:682-691.

5. Nemerson, Y., and R. Bach. 1982. Tissue factor revisited. Prog. Hemostasis. Thromb. 6:237-261.

6. Hendrix, H., T. Lindhout, K. Mertens, W. Engels, and H. C. Hemker. 1983. Activation of human prothrombin by stoichiometric levels of staphylocoagulase. J. Biol. Chem. 258:3637-3644.

7. Broze, G. J., Jr., and P. W. Majerus. 1980. Purification and properties of human coagulation Factor VII. J. Biol. Chem. 255:1242-1247.

8. Miletich, J. P., G. J. Broze, Jr., and P. W. Majerus. 1980. The 
synthesis of sulfated dextran beads for isolation of human coagulation Factors II, IX and X. Anal. Biochem. 105:304-310.

9. Sande, M. A., and R. G. Irvin. 1974. Penicillin-aminoglycoside synergy in experimental Streptococcus viridans endocarditis. J. Infect. Dis. 129:572-576.

10. Rodgers, G. M., C. S. Greenberg, and M. A. Shuman. 1983. Characterization of the effects of cultured vascular cells on the activation of blood coagulation. Blood. 61:1155-1162.

11. Rodgers, G. M., V. H. Donaldson, and M. A. Shuman. 1982. Radioisotopic measurement of plasma kallikrein. Thromb. Res. 27:641649.

12. Fenton, J. W., and M. J. Fasco. 1974. Polyethylene glycol 6000 enhancement of the clotting of fibrinogen solutions in visual and mechanical assays. Thromb. Res. 4:809-817.

13. Broze, G. J., Jr. 1982. Binding of human Factor VII and $\mathrm{VII}_{\mathrm{a}}$ to monocytes. J. Clin. Invest. 70:526-535.

14. Tracy, P. B., M. S. Rohrbach, and K. G. Mann. 1983. Functional prothrombinase complex assembly on isolated monocytes and lymphocytes. J. Biol. Chem. 258:7264-7267.
15. Rodgers, G. M., and M. A. Shuman. 1983. Prothrombin is activated on vascular endothelial cells by Factor $\mathrm{X}_{\mathrm{a}}$ and calcium. Proc. Natl. Acad. Sci. USA. 80:7001-7005.

16. Johnsen, U. L. H., T. Lyberg, K. S. Galdal, and H. Prydz. 1983. Platelets stimulate thromboplastin synthesis in human endothelial cells. Thromb. Haemostasis. 49:69-72.

17. Colucci, M., G. Balconi, R. Lorenzet, A. Pietra, D. Locati, M. B. Donati, and N. Semerara. 1983. Cultured human endothelial cells generate tissue factor in response to endotoxin. J. Clin. Invest. 71:1893-1896.

18. Niemetz, J., and A. J. Marcus. 1974. The stimulatory effect of platelets and platelet membranes on the procoagulant activity of leukocytes. J. Clin. Invest. 54:1437-1443.

19. van Ginkel, C. J. W., L. Thörig, J. Thompson, J. I. H. Oh, and W. G. van Aken. 1979. Enhancement of generation of monocyte tissue thromboplastin by bacterial phagocytosis: possible pathway for fibrin formation on infected vegetations in bacterial endocarditis. Infect. Immun. 25:388-395. 